\title{
Transforming Growth Factor Beta-1
}

National Cancer Institute

\section{Source}

National Cancer Institute. Transforming Growth Factor Beta-1. NCI Thesaurus. Code C20457.

Transforming growth factor beta-1 (390 aa, $44 \mathrm{kDa}$ ) is encoded by the human TGFB1 gene. This protein is involved in cell proliferation, cell death and a large number of signal transduction pathways. 